\title{
LOODUSTEADUSTE ÕPIKUTE KEELEST
}

\author{
KERSTI LEPAJÕE, \\ KÄRT TALSI, LIISA TEPP
}

\begin{abstract}
Annotatsioon. 2011. aastal tellis Haridus- ja Teadusministeerium Tartu Ülikoolilt loodusainete õpikute keelekasutuse hindamise. Töö eesmärk oli selgitada, kuidas mõjutab õpiku keelekasutus teksti loetavust ja arusaadavust. Artiklis lähtutakse Michael A. K. Halliday teksti metafunktsioonide määratlusest. Õpikutekstide kvalitatiivse analüüsi tulemusena võib tõdeda, et õpikutekstid on staatilised, inimtegelased on neist taandatud, teksti osalisteks on ained või abstraktsed mõisted. Väljenduslaadilt on õpikutekst neutraalne, kuid koormatud suure hulga terminitega. Interpersonaalsuse analüüs näitab, et õpiku autor kirjutab teadja positsioonilt, lugejale on jäetud passiivse vastuvõtja roll. Tekstisidususvahendeid on enamasti eesmärgipäraselt kasutatud, üksikuid kõrvalekaldeid esineb uue ja vana info esitamises. Kvantitatiivse analüüsiga selgitatakse, et uute terminite hulk on õpikutekstis suur, pealegi ei esitata termineid piisava sagedusega, et need kinnistuksid. Lause pikkuse ja pikkade sõnede osakaalu põhjal saab järeldada, et loodusteaduste õpikute keel on keeruline, selle põhjuseks on erialaspetsiifiliste terminite suur osakaal tekstis ja nende vähene korduvus. Kohati ei soosi arusaadavust vildakad viitesuhted ning vana ja uue info esitamise loogika eiramine. Võtmesõnad: õpikuteksti loetavus, teksti tähistusfunktsioon, interpersonaalsus, tekstuaalne funktsioon, terminid, pikad sõnad, lause pikkus, teksti keerukus, eesti keel
\end{abstract}

2011. aastal tellis Haridus- ja Teadusministeerium Tartu Ülikoolilt loodusainete õpikute keelekasutuse hindamise. Õpikukeele uurimine on vastavuses „Eesti keele arengukava 2011-2017” (EKAK) tegevustega, kus keelearendustööle üldhariduskoolis pööratakse suurt tähelepanu. Emakeele Selts vahendas uurimisülesannet ning see jaotus Tartu Ülikooli ja Tallinna Ülikooli vahel. Tartu Ülikooli vastutusvaldkonnaks oli Koolibri kirjastuse loodusteaduste õpikute keelekasutuse hindamine. Uurimisülesande raames valmis 2012. aasta kevadel kaks magistritööd: Kärt Talsi „Keemiaõpiku loetavuse analüüs” ja Liisa Tepi „Erinevate hindamismeetodite 
rakendamine õpiku analüüsis". Magistritööde põhitähelepanu keskendus loodusteaduste õpikute keelekasutusele, teksti loetavusele ja keerukusele. Põhiline uurimisküsimus oli, kas õpikutes kasutatav keel on piisavalt eakohane ja sobiva keerukusastmega edastamaks aine sisu või raskendab keerukas keelekasutus, sh terminikasutus, õpikutekstist arusaamist.

\section{1. Õpik õppevarana ja õpikute uurimine}

Traditsiooniliselt on mõistetud õpikut kui vahendit, mille abil üks või teine aine omandatakse kas õpetaja toel või iseseisvalt õppides. Viimast arvestades on oluline, et õpik oleks kirjutatud õpilasele arusaadavalt. Õpik peab toetuma käibivale õppekavale ja peale sisu andma edasi ka õppekavas kehtestatud pädevusi. Teisalt on õpik alati tekst, st õpik on kirjutatud keel, millel on lineaarne edenemine ja sõltumatus ajast või ruumist. Kui ka õpik tehnoloogiliste vahendite arenedes oma vormi muudab, jääb see siiski tekstiks. On ilmne, et tekstide najal omandatakse keel kogu selle keerukuses ja funktsioonide paljususes. Ka õpikutekstil on oluline tähendus keeleoskuse kujunemisel: erialasõnavara ja teadusliku keelekasutusega tutvuvad õpilased eelkõige õpikutekstide kaudu. Just teaduslikku keelekasutust on põhjust rõhutada, sest teaduse aluseid ja intellektuaalsfääri tekstidest arusaamist pole võimalik omandada asjakohast keelekasutust tundmata.

Õpiku-uuringutega on põhjalikult tegelnud Tartu Ülikooli professor Jaan Mikk, kelle järgi peaks õpik täitma järgmisi ülesandeid: innustama õppima, andma teavet, süstematiseerima teadmisi, suunama ja juhendama, õpetama õppimisstrateegiaid, võimaldama enesehindamist, võimaldama diferentseeritud õpet ja kujundama väärtushinnanguid. Õpiku kvaliteedi hindamiseks on J. Mikk soovitanud analüüsida õpiku sisu, loetavust, ülesehitust, ülesandeid, illustratsioone, enesehindamiseks mõeldud küsimusi, probleeme ja kontrollülesandeid. (Mikk 2000: 20-22)

Siinse artikli huvikeskmeks on õpikuteksti loetavus. Eeldatavasti peaks õpikuteksti olema kerge lugeda, see peaks olema eakohane ja arusaadav. Liiga keerukas tekst võib tekitada võõrandumist ja huvi vähenemist õppeaine vastu. Michael A. K. Halliday leiab, et võõrandumises pole süüdi mitte kitsalt õpikute keelekasutus, vaid laiemalt kogu teaduse keel, mis on inimestest kaugenenud ja võõraks muutunud. Koolis kasutatakse palju õpilasepäraseks kohandatud teaduskeelt (Halliday 2007 (1993): 199-200). Kuigi õpikutekstid on teadustekstidega võrreldes lihtsustatud, võib 
loodusteaduste õpikutes siiski sageli kohata liiga keerulisi tekste. Sellisest tekstist on raske kätte saada teavet, see omakorda pärsib aga õpiedukust. Ka viimastel aastatel ilmnenud vähenenud huvi loodusteaduste õppimise vastu (Holbrook, Rannikmäe 2007: 1348) võib olla seotud õpikute liiga keerulise keelekasutusega.

Krista Kerge on juhtinud tähelepanu sellele, et gümnaasiumiastmes tuleks tegelda muude tekstide kõrval ka keerukate teadustekstidega, et valmistada õpilasi ette eluks ja kokkupuuteks eri raskusastme tekstidega (Kerge 2003: 42). See väide peegeldab viimastel aastatel järjest enam levima hakanud arusaama, et eesti keelt ei õpita ainult eesti keele tundides, vaid seda tehakse ka teiste ainete tundides. Üks võimalus õpetada õpilasi paremini teadustekstidega toime tulema oleks see, kui õppetöös rohkem kasutataks kohandatud teadustekste (ingl adopted primary literature ehk APL). Võrreldes teadusartiklitega on selliste tekstide sõnastust lihtsustatud, ometi järgivad kohandatud tekstid teadusartikli ülesehitust. Õpikutekstidega võrreldes on sellistel tekstidel see eelis, et erinevalt õpikust, kus materjal esitatakse lihtsalt faktidena, võimaldavad kohandatud tekstid jälgida arutluskäiku, poolt- ja vastuargumente jms. Iisraeli autorid Ayelet Baram-Tsabari ja Anat Yarden (2005) on näidanud, et kohandatud teadustekstid aitavad õpilastes juurutada teaduslikku mõtteviisi. Õpikutekstid kujundavad Ayelet Baram-Tsabari ja Anat Yardeni väitel harjumust pinnapealselt lugeda.

Riiklikus õppekavas on suurt tähelepanu pööratud loodusteaduste ja tehnoloogilise kirjaoskuse kujundamisele, kuid see tähendab kirjaoskust ülekantud, mitte lingvistilises tähenduses. Tekstidega tegelemisele viitab õppekavas olev nõue suunata õpilasi kasutama mitmesuguseid teabeallikaid, sealhulgas internetti, ja õpetada teabeallikate usaldusväärsust kriitiliselt hindama. Eeldatakse ka loodusteaduste keele korrektse kasutamise arendamist (Õppekava 2011:25). Ainekavad on üsna üldsõnalised ja neist pole võimalik välja lugeda, kui põhjalikult üht või teist valdkonda peaks käsitlema. Õpilane peaks omandama süsteemse ülevaate loodusteaduste põhimõistetest (samas: 25), ent millistest ja kui paljudest, seda ei täpsustata. See omakorda tingib olukorra, kus õpikute autoritel on üsna vaba voli valida, kui palju ja milliseid mõisteid õpikutes esitada ja millist terminoloogiat selleks kasutada.

Arusaamad õpikukeelest ja nende muutumine on seotud asjakohase valdkonna uuringutega. Eesti on selles mõttes üsna heas seisus, sest vii- 
mastel aastakümnetel on seesuguse temaatikaga süsteemselt tegeldud. Üks teenekamaid õpiku-uurijaid-teoreetikuid on professor Jaan Mikk, kelle „Teksti mõistmine” (1980) ja „Didaktika küsimusi: loengukonspekt üliõpilastele" (1991) on teed rajava tähtsusega. Peale selle on J. Mikk avaldanud hulganisti artikleid (nt Mikk 1995, 2003), kutsudes neis üles autoreid kirjutama loetavamaid ja õpilastele arusaadavamaid elulähedasi õpikuid. J. Mikk on aidanud välja töötada ka eestikeelsete õpikute keerukuse analüüsi programmi (Asser jt 2004). Selle programmiga uuriti põhikooli eesti keele kui võõrkeele õpikuid. Õpikukeele poolelt jäävad J. Miku töödest kõlama järgmised soovitused: õpiku laused olgu lühikesed, abstraktseid ja tundmatuid sõnu kasutatagu võimalikult vähe, omandamiseks mõeldud sõnu ja termineid korratagu piisavalt sageli. J. Mikk nendib ise, et Eestis on aja jooksul jõutud nii kaugele, et õpikulaused on enamasti piisavalt lühikesed, vahel liigagi. Seevastu õpikute elulähedasemaks muutmine, nende abstraktsuse vähendamine pole õnnestunud. (Mikk 2003)

Põhjalikult on õpiaja sõltuvust matemaatika, füüsika ja astronoomia õppeteksti omadustest uurinud Hasso Kukemelk. Teksti iseloomustavate tunnustena on ta vaadelnud selle huvitavust, erialaste mõistete ja terminite hulka ning nendevaheliste seoste arvu, nimisõnade protsenti, kirjavahemärkide arvu, valemite arvu, keskmist sõnapikkust, pikkade nimisõnade osatähtsust ja tekstis esinevate nimisõnade abstraktsust (Kukemelk 1990a, 1990b). Selle alusel töötas ta välja valemi, millega saab mõõta õpiaja sõltuvust teksti raskusastmest. Kukemelgi valemi rakendamise teeb keerukaks suur töömaht, keeruliste mõistegraafide ja punktjoonskeemide koostamine.

Tervikõpikute keele uurimisel on edukalt kasutatud veidi lihtsamaid võtteid, mis pole nii töömahukad. Helin Puksand $(2004,2005)$ on vaadelnud näiteks terminite korduvust õpikus ja kasutanud Rootsist pärit loetavusindeksit LIX, mis kombineerib pikkade sõnede esinemissagedust ja lausete pikkust. Sel viisil uuris ta 11 põhikooliõpikut. Kokkuvõtva ülevaateartikli õpikute keele uurimisest Tallinna Ülikoolis on kirjutanud Helin Puksand ja Krista Kerge (2011). Tallinna Ülikoolis tehtud uuringutes on mõõdetud tekstide raskusastet loetavusindeksiga LIX, formaalsuse astet, nominaalsust, terminikasutust, leksikaalset tihedust ning analüüsitud õpilaste sõnavara rikkust. Autorid näitavad, et õpiteksti raskus on kõigi nende parameetritega seotud, kuid on seejuures suhteliselt sõltumatu ja seotud lugemistehnikaga. Nominaalsus ja leksikaalne tihedus moodustavad selguse ja arusaadavuse faktori, millega seostub väljendustäpsust näitav 
formaalsus. Autorid nimetavad, et kohati on uuritud õpikutekstid keerukamad täiskasvanutekstidest. Teksti raskusfaktorite mõju aitab kahandada aja- ja eakohane õpikute kujundus. (Puksand, Kerge 2011)

\section{Uurimismeetod ja -materjal}

Siinse artikli uurimismeetodiks on lingvistiline tekstianalüüs. Töös lähtutakse M. A. K. Halliday (2004: 29-31) süsteemfunktsionaalse grammatika metafunktsioonide esitusest. Halliday nimetab metafunktsioonidena tähistusfunktsiooni, interpersonaalset ehk suhtlusfunktsiooni ja tekstuaalset funktsiooni. Tähistusfunktsioon loob pildi maailmast ja kogemustest, interpersonaalne funktsioon kujundab ja säilitab sotsiaalseid suhteid. Lingvistilises tekstianalüüsis pööratakse tähelepanu aga tekstuaalsele funktsioonile, mis konstrueerib teksti mõttekaks tervikuks. Täpsemalt uuritakse selle juures järgmisi nähtusi: teksti liiki ja registrit kujundavaid keelevahendeid, infostruktuuri, tekstisidusust ehk kohesiooni ja teksti intertekstuaalsust.

Siinses artiklis analüüsitav materjal pärineb Mati Karelsoni ja Aarne Tõldsepa õpikust „Keemia. Üldine ja anorgaaniline keemia gümnaasiumile” (2011) ja Liisa-Kai Pihlaku ja Andres Tõnissoni õpikust „Geograafia põhikoolile: Eesti ja Euroopa" (2005).

Keemiaõpik jaguneb viieks suuremaks teemaplokiks: 1) sissejuhatus üldisesse ja anorgaanilisse keemiasse; 2) aine ehitus; 3) keemilised reaktsioonid; 4) metallide keemia; 5) mittemetallide keemia. Teemaplokid jaotuvad omakorda peatükkideks, mõni peatükk ka alapeatükkideks. Peatükid ja alapeatükid koosnevad suurelt jaolt kohustuslikust tekstist, mille kõrval on ka mittekohustuslikku teksti lisalugemiseks. Kuna peatükid on väga erineva pikkusega (1-7 lk), siis võib arvata, et nende koostamisel on lähtutud pigem õppeaine struktuurist, mitte aga õppetunniks sobivast ainemahust. Tekstis leidub esiletõstetud osi: Mis sa arvad?, Ära unusta!, Mõtle, otsusta, lahenda!. Ülesanded asuvad suuremate plokkidena osade lõpus. Põhimaterjalile lisandub 12 lehekülge mõistete selgitusi, aineregister, nimeregister ja keemiatabelid. Kokku on õpikus 265 lehekülge.

Geograafiaõpik koosneb neljast teemaplokist: 1) Eesti loodusgeograafia; 2) Eesti rahvastikugeograafia; 3) Eesti majandusgeograafia; 4) Euroopa geograafia. Iga teemaplokk koosneb peatükkidest ja alapeatükkidest ning iga peatüki lõpus on kokkuvõte. Erandiks on vaid 1. peatükk „Eesti loodus- 
geograafia", kus peatüki mahukuse tõttu on kaks kokkuvõtet. Kokkuvõte hõlmab tähtsamaid fakte (Kordamine), enesekontrolliharjutusi (Kontrolli ennast, kas sa tead!), kaardi kasutamise harjutamist (Näita kaardil!) ja sõnavaraharjutusi (Tuleta meelde oskussõnade tähendusi!). Peatükkides esitatud tekstide juurde kuuluvad ka lisalugemine, illustreeriv materjal, ülesanded, eraldi on märgitud tähtsamad terminid. Õpiku juurde kuulub oskussõnastik ja ülevaatlik tabel geoloogilise ajaarvamise kohta. Kokku on õpikus 199 lehekülge.

\section{Tähistusfunktsioon}

Tähistusfunktsiooni vaadeldakse põhiliselt Karelsoni ja Tõldsepa keemiaõpiku najal. Kõrvutavaid näiteid tuuakse Pihlaku ja Tõnissoni geograafiaõpikust. Analüüsitavad keemiaõpiku peatükid on „Metallilised elemendid keemiliste elementide perioodilisustabelis" (Karelson, Tõldsepp 2011: 126-128), „Metallid looduses” (samas: 128-131) ja „Metallide tootmine” (samas: 131-136). Nendes peatükkides esineb palju ainesõnu. Teksti osalistena kerkivad esile keemilised elemendid ja nende rühmad ning abstraktsed mõisted: metallilised elemendid, B-rühmade elemendid, lihtained, 5 f-elemendid, raud, koobalt, mineraalid, protsessid, redutseerimine, materjal. Võimalikud inimosalised on tekstist taandatud. Enamasti on see saavutatud nii, et lause grammatiliseks aluseks on tehtud ainesõna või abstraktne mõiste: siirde- ehk üleminekumetallid moodustavad omamoodi sujuva ja aeglase ülemineku perioodilisustabelis aktiivsetelt metallidelt mittemetallidele. Teise võimalusena on kasutatud umbisikulist tegumoodi ja üldisikut, kusjuures selliste lausete hulgas tõuseb esile kaks rühma, mida iseloomustavad

1) nimetamine: kõiki I A-rühma metalle nimetatakse leelismetallideks; aluspõhi on pinnakatte alla mattunud (vahel ka maapinnal avanenud) kivimid;

2) aktiivsed protsessid, mis on võimalikud ainult inimese osalusel, kuid inimosalust ei näidata: vajaliku temperatuuri saavutamiseks pumbatakse kõrgahju alt veel ka eelsoojendatud õ hku; täna hinnatakse Eesti pärandkoosluse pindalaks 75000 ha, mis on umbes 20 korda vähem kui sajand tagasi.

Niiviisi on saavutatud tekst, milles lugeja tähelepanu keskendub eelkõige nähtustele ja asjadele kui millelegi staatilisele ja igikestvale. Staatilisuse 
taotlus on tavaline ka teadustekstide puhul ja üks võimalus seda saavutada on muuta pöördeline tegusõnavorm käändeliseks. Sel viisil saadud nominalisatsioone leidub ka analüüsitavates tekstides küllaga: maakide ettevalmistamine metallide redutseerimiseks; raua redutseerumine toimub kõrgahjus; soo arenemine algab madalsooga. Teine võimalus staatilisust rõhutada on see, kui ajavormidest kasutatakse ainult kindla kõneviisi olevikku. Nii näiteks on keemiaõpiku peatüki „Metallide tootmine” alguses (Karelson, Tõldsepp 2011: 131-135) kasutatud järjekindlalt oleviku ajavorme (nii isikulises kui ka umbisikulises tegumoes, kuid alati kindlas kõneviisis). Nende ajavormide abil on kirjeldatud metallurgilisi protsesse, üksikjuhul kõrgahju tööd, kui midagi üldkehtivat. Kõrgahju esitatakse selles tekstis kui nähtust, mis on alati olemas olnud, ei kao kunagi ja töötab igas olukorras ühtemoodi.

Tähenduste loomine ülalkirjeldatud moel on suhtlusfunktsiooni ja žanritavade teenistuses. Kui asjade ja nähtuste esiplaanile seadmine lähendab õpikut teadustekstile, siis oleviku ajavormide abil kõigutamatute tõdede esitamist on Anat Yarden pidanud just õpikule iseloomulikuks. Yarden (2009: 308) näitab, et õpikut kui ekspositoorset ehk eritlevat teksti iseloomustab see, et väiteid esitatakse kindlate tõdedena ja pakutavaid tõdesid ei toetata tõenditega. Seevastu pigem argumenteerivasse tekstitüüpi kuuluvates teadusartiklites esitatakse väiteid ebakindlana ja toetatakse tõendusmaterjaliga. Niisiis võib tüüpilise teadusartikli ja õpiku erinevuse sõnastada nii, et esimeses peetakse vaidlust teaduse loomulikuks osaks ja lugejalt eeldatakse kahtlemist, teises aga konstrueeritakse lugeja roll nii, et ta oleks lihtsalt vastuvõtja, kes ei sea esitatavaid väiteid kahtluse alla. Siinses artiklis analüüsitava materjali põhjal on teksti ajavormide ja kõneviisi valik valdavalt just viimati mainitud lugejarolli teenistuses.

Enamasti on analüüsitavate õpikute tekstis püütud väljenduda neutraalselt, mis on iseloomulik teadustekstile. Omadussõnu on vähe ning enamasti on need objektiivsed ja tehnilised: söövitav toime, leeliselised omadused, happelised huumusained, lahustuvad ühendid. Aeg-ajalt on tekstis siiski ka hinnangulisi väljendeid: metallide tootmise keskseimaks protsessiks on kahtlemata metalli redutseerimine lihtaineks rikastatud ja ettevalmistatud ühendist; Eesti kõige viljakamad - leostunud ja leetjad mullad - on levinud Pandivere kõrgustikul. Selles võib näha katset õpiku muidu neutraalset stiili veidi elavdada ja emotsionaalsemaks muuta, et 
lugeja tähelepanu enam köita. Kokkuvõttes on modaalsust aga nii vähe, et see võib mõjuda ka kõrvalekaldena teksti üldisest stiilist.

Protsessid, mida analüüsitavas tekstis kirjeldatakse, on suures osas eksistentsiaalsed (esineb, see kujutab endast, jäädes tekkinud malmi koostisse, leidub), palju kasutatakse olema-tegusõna. Rohkesti esineb ka mõistetevahelisi suhteid märkivaid verbe (koosneb, kuulub, moodustavad). Suur osa kujutatavatest protsessidest on seega passiivsed ja staatilised, mis on iseloomulik kirjeldavale ja eritlevale tekstitüübile. Eelkõige on verbide valik tingitud tavast ja teemast. Kuna teemaks on elutud objektid ja abstraktsed nähtused, mida tarbetekstides on seni olnud tavaks kujutada passiivses rollis, siis on sellise valiku teinud ka õpikute autorid.

Mentaalsetest protsessidest on ülekaalus nimetamine (nimetatakse), veidi esineb ka klassifitseerimisele viitavaid verbe (on võetud aluseks, käsitletakse, loetakse). Nimetamist ei esine peatükkides ühtlaselt. Sagedasem on nimetamine seal, kus tutvustatakse valdkonna terminoloogiat. Näiteks keemiaõpiku peatüki „Metallilised elemendid keemiliste elementide perioodilisustabelis" põhitekstis esineb nimetamist 17 korda (grammatilisi lauseid on selles tekstilõigus 41). Niisiis on selle peatüki keskne eesmärk terminisüsteemi esitamine, et viia õpilane kurssi teadusala oskuskeelega. Sellise teksti struktuur on küllaltki lihtne, ent katkendlik. Tekib hulk kaheja kolmeliikmelisi mõisteahelaid: 1) nähtust A nimetatakse terminiga B või 2) nähtust A nimetatakse terminiga $B$, kusjuures nimetuse alus on $C$. Sellist ahelat on üksikuna küllaltki lihtne mõista, ent kuhjudes teevad need teksti üksluiseks ja koormavad seda oskussõnadega, mille tagajärjel halveneb loetavus.

\section{Interpersonaalne funktsioon}

Õpikute analüüsi alusel võib tõdeda, et lugejale on konstrueeritud sellise vastuvõtja roll, kes ei esita küsimusi. See kehtib õpikute põhiteksti kohta. Kui aga vaadelda teksti osi eraldi, siis määrab interpersonaalsed suhted tekstilõigu tüüp. Keemiaõpikus kasutatakse ainsuse teises pöördes küsimust peatüki alguses (Mis sa arvad?), geograafiaõpikus peatüki lõpus (Kontrolli ennast, kas sa tead!, Näita kaardil!, Tuleta meelde oskussõnade tähendusi!, Jäta meelde!). Peatükkide sisu on kas ainsuse kolmandas pöördes või umbisikuline, mõnes üksikus kohas on kasutatud ka mitmuse esimest pööret, aga pea alati on põhitekst kindlas kõneviisis. Modaalsust 
esineb vähe ja see on pigem juhuslik kui järjekindel. Kirjutaja on kujundanud endale seega teadja rolli, kuid püüab tekstis endale mitte viidata, jääda neutraalseks, mitte asuda õpetama või veenma. Hinnangutest on autorid enamasti hoidunud ja peitväiteid pole kasutanud. Sel viisil esitatud infole oleks põhimõtteliselt küll võimalik vastu vaielda, ent neutraalne ja umbisikuline esitus ei ajenda lugejat seda tegema. Niisugustest valikutest peegeldub kõige enam soov näidata käsitletavat materjali üldkehtiva tõena, mida pole vastavas teadusharus kombeks kahtluse alla seada ja mille lugeja peaks pikemalt arutlemata teadmiseks võtma. Endale teadja rolli võttes teevad autorid lugejast passiivse osalise, peatüki alguse sissejuhatavate küsimustega püütakse seda suhet siiski pisut leevendada. Selline võte, kus autor kui teadja positsioonil olev kirjutaja jätab lugeja passiivsesse rolli, on omane õpikule kui tekstiliigile üldisemalt, seega ei ole Karelsoni, Tõldsepa keemia- ega ka Pihlaku ja Tõnissoni geograafiaõpik ses mõttes mingi erand.

\section{Tekstuaalne funktsioon}

\subsection{Infostruktuur}

Lause info- ehk teatestruktuur väljendub selles, kuidas on esitatud lugejale uut ja vana infot ning kuidas on olulist infot rõhutatud. Infostruktuuri kirjeldamiseks kasutatakse siinses artiklis termineid teema ja reema. Teema on see osa lausest, mille kohta midagi öeldakse, reema aga ülejäänud lauseosa ehk see, mida öeldakse (EKG 1993: 192-193). Kuna kirjalikes tekstides on enamasti teema lauses esimesel kohal ja reema viimasel, siis on ka õpikutekstis mõistlik sellisest teema-reema paigutusest kinni pidada. Muidu võib lugeja lauset valesti tõlgendada ja pidada oluliseks lauseosa, mida kirjutaja tegelikult rõhutada ei tahtnud.

Teksti loetavuse seisukohalt on lause teatestruktuur väga oluline. Näiteks kui kahe lause lõppu on paigutatud üks ja sama reema, siis peab lugeja hakkama lauseid üle lugema, et neid uuesti tõlgendada ja leida üles tegelik uus info.

(1) Sõltuvalt aatomi ehitusest ning sellest tulenevatest liht- ja liitainete omadustest kasutatakse erinevate metallide rühmade puhul veel ka erinevaid üldnimetusi:

- kõiki I A-rühma metalle nimetatakse leelismetallideks, 
- II A-rühma metalle alates kaltsiumist nimetatakse leelismuldmetallideks,

- kõiki B-rühmade metalle nimetatakse siirde- ehk üleminekumetallideks,

- 6. perioodi III B-rühma metalle (58-71), millele vastab nende aatomites 4f-orbitaalide täitumine elektronidega, nimetatakse lantanoidideks,

- 7. perioodi III B-rühma metalle (90-103), millele vastab nende aatomites 5 f-orbitaalide täitumine elektronidega, nimetatakse aktinoidideks.

(2) I A-rühma metalle nimetatakse leelismetallideks, sest kõik nende hüdroksiidid ( $\mathrm{LiOH}, \mathrm{NaOH} \mathrm{jt}$ ) on tugevad leelised: nad lahustuvad hästi vees ja on söövitava toimega.

(3) Leelised tekivad juba nende metallide reageerimisel veega.

(4) II A-rühma kaltsiumi-alarühma metallide üldnimetus leelismuldmetallid viitab samuti nende hüdroksiidide leeliselistele omadustele.

(5) Siin aga on silmas peetud nende oksiidide omadust moodustada veega leeliseid.

(kõik näited Karelson, Tõldsepp 2011: 127)

Esialgu on infostruktuur põhjendatud. Esimeses lauses on rõhk sõnal üldnimetusi, mida järgnevas täpploetelus hakataksegi eritlema. Loetelupunktide sees omakorda on rõhk uutel terminitel, mis on esile tõstetud nii lause teatestruktuuri kui ka poolpaksu kirjaga. Esimene ebakõla tekib aga kõrvallausetes millele vastab nende aatomites 4 -orbitaalide täitumine elektronidega ja millele vastab nende aatomites 5 -orbitaalide täitumine elektronidega. Kuna ainus erinevus on siin 4 -orbitaalide ja 5 -orbitaalide vahel, siis peaksid just need sõnad kui eristavad elemendid olema kõrvallauses tähtsaimal kohal, st viimased. Analüüsitavas näites on nad eespool. Järgmiseks hakatakse loetelu punkte lahti kirjutama. Teise lause teema on A-rühma metalle ja reema tugevad leelised, seejärel eelnenud väidet põhjendatakse. Kolmanda lause teemaks on võetud eelmise lause reema (leelised), mis on väga levinud võte ja teemaarenduse seisukohalt igati loogiline. Kolmanda lause sees kinnitavad sõnad nende metallide veel kord sidet eelmise lausega, viidates teise lause sõnale leelismetallid ja olles seega samuti vana info. Piir kolmanda lause teema ja reema vahel läheb seega vahetult enne sõna veega, mis asub rõhulisel kohal. Neljas lause jutustab ümber teise loetelupunkti, ka siin on teema-reema järgnevusega kõik korras. Viiendas lauses tekib aga segadus. Nimelt on siin viimasel 
kohal sõna leeliseid, mis tõlgendatakse esialgu reemaks. Kuna tegu on eritleva tekstiga, siis saab lugeja aru, et viimase sõnaga peabki olema edasi antud eristav tunnus. Et vaadata, mis oli eelmise kirjeldatud rühma (leelismetallide) eristav tunnus, pöördub lugeja tagasi lõigu algusesse ja leiab teisest lausest, et seal on reema positsioonis samuti leelised. Erinevus peab olema seega kuskil mujal. Kui lugeja veel ei loobu, siis ta pöördub ehk tagasi viienda lause juurde ja leiab eelviimaselt positsioonilt sõna veega. Eelnenud lauseid uuesti üle lugedes märkab ta, et ka vesi ei saa olla eristav tunnus, sest veega reageerimisest on räägitud ka kaheksandas lauses. Kui seegi tunnus on välistatud, siis leiab lugeja pika otsimise peale, et rühmi saab eristada selle põhjal, kas veega reageerivad puhtad metallid või hoopis metallioksiidid. See kirjeldus võib olla ainus tee, kuidas tekstilõigust õige mõte üles leida. Tõenäoliselt kaob problemaatilise viienda lause juures lugejal aga mõttekäik käest.

Teksti autoril on selliseid teema-reema vastuolusid raske märgata, sest tema jaoks on kogu materjal väga põhjalikult tuttav ja seega ühtviisi vana info. Õpilane loeb aga teksti esimest korda ja käsitletav aines on tema jaoks võõras. Tarbeteksti puhul pole mingit põhjust eeldada, et oluline info võiks olla esitatud ootamatus kohas, niisiis võib tavapärasest teemareema struktuurist hälbimine teksti mõistetavust väga tugevalt häirida.

Sellise lause infostruktuuri saab üsna lihtsate vahenditega parandada. Üks võimalus on tõsta rõhutatav fraas (metallide oksiidid) reema positsiooni.

Siin on aga silmas peetud nende oksiidide omadust moodustada veega leeliseid.

$\rightarrow$ Siin on aga silmas peetud asjaolu, et leelised moodustuvad siis, kui veega reageerivad nende metallide oksiidid.

Enamasti ei tekita infostruktuuri vastuolud nii suurt segadust, kuid pidurdavad siiski lugemist. Näiteks järgmise tekstikatke teemaarendus oleks märksa sujuvam, kui tekstist jätta välja teine lause.

(6) Maakide ettevalmistamise hulka kuuluvad sellised protsessid nagu maagi peenestamine ja kuivatamine ning lisandite eemaldamine. Metallimaakides olevaid lisandeid nimetatakse aheraineks. Kõik need protsessid üheskoos kannavad üldnimetust - maakide rikastamine. (Karelson, Tõldsepp 2011: 132) 
Tekstikatkes on küll teemaarendus esimeselt lauselt teisele loogiline, ent teise ja kolmanda lause vahel tekib mõtteauk, sest kolmanda lause teema kõik need protsessid algab kokkuvõtva sõnaga, mis oleks loogiline seostada vahetult eelneva lausega, ent mis sisult viitab hoopis üle-eelmisele lausele.

Eelneva põhjal võib tõdeda, et infostruktuuri korrastamine õpikutekstides parandaks loetavust ja aitaks õpilastel õppeainest väiksema vaevaga aru saada.

\subsection{Teksti sidusus ehk kohesioon}

Sidusus ehk kohesioon on teksti leksikaal-grammatiliste seoste võrgustik, mis on keeleliselt vormistatud ehk sõnaliselt eksplitseeritud. Kohesioon esineb kõikjal, kus teksti ühe elemendi tõlgendamine sõltub sama teksti teise elemendi tõlgendamisest. Olulisemad kohesioonivahendid on kordus, asendus (pronoomenid, sünonüümid) ja ellips, aga ka sõnade semantilistel suhetel ja ühisesse tähendusvälja kuulumisel põhinevad seostamisviisid (antonüümia, hüponüümia, osa ja terviku suhted jms). Ühise tähendusvälja äratundmine ja piiritlemine põhineb suuresti teksti kirjutaja ja lugeja ühistel pragmaatilistel teadmistel (Halliday, Hasan 1976: 285-287, 298-300, 324-327).

Põhiline vahend viitesuhete loomiseks õpikutekstis on asendussõnad. Neid kasutatakse mõõdukalt ja enamasti on selge, millele viidatakse.

(7) Looduses leidub metalle nii lihtainetena kui ka väga erinevate liitainete koostises. Kõiki neid käsitletakse üldjuhul mineraalidena. (Karelson, Tõldsepp 2011: 128)

(8) Germaaniumi leidub looduses küll suhteliselt palju - rohkem kui kõiki väärismetalle kokku -, ent temagi esineb looduses väga hajutatult. See on ka üks peamisi põhjusi, miks germaanium avastati väärismetallidega võrreldes suhteliselt hilja, aastal 1886. (Karelson, Tõldsepp 2011: 129)

Teisalt võib leida ka näiteid selle kohta, kuidas viitesuhted ei aita teksti tervikuks siduda. Metallide tootmist käsitlevas peatükis alustatakse tootmisprotsesside kirjeldust kolmeliikmelise loeteluga. Seejärel näidatakse sõnaga esimest, et loetelu kavatsetakse edaspidi süsteemselt käsitlema hakata.

(9) Metallid redutseeritakse peamiselt kolmel meetodil: pürometallurgiliselt, elektrometallurgiliselt ja hüdrometallurgiliselt. Esimest meetodit 
kasutatakse valdavalt oksiidsete maakide puhul, kus redutseerijatena kasutatakse sütt (õigemini koksi) süsinikoksiidi, vesinikku, alumiiniumi ja teisi metalle. (Karelson, Tõldsepp 2011: 132)

Järgneb esimese meetodi põhjalik kirjeldus, mis võtab enda alla ligi kaks lehekülge. Seejärel hakatakse käsitlema elektrometallurgiat, kuid see pole tekstis varasema loeteluga eksplitsiitselt seotud.

(10) Kõik elektrometallurgilised metallide tootmisviisid põhinevad kas sulatatud soolade või nende vesilahuste elektrolüüsil. (Karelson, Tõldsepp 2011: 135)

Kolmandat meetodit ehk hüdrometallurgiat aga mainitaksegi vaid üks kord. Sel viisil rippuma jäänud viide loob lugejale teksti struktuurist vale kujutluse. Lugejale oleks enam abiks see, kui viidetega markeeritakse kogu käsitletav üksus.

Tekstisidususvahendid on ka sidendid ja muud seosesõnad, mille kasutamise võimalustest on hea ülevaate andnud Reet Kasik (2007: 30-31). Tendentsina ilmneb, et õpiku peatükkide alguses on rohkem lisavaid seosesõnu (samuti, peale selle, veel ka, nii .. kui ka, või ka), hiljem lisanduvad neile vastandavad ja möönvad (aga, mitte niivõrd .. kui, seevastu, mitte aga, küll .. ent), seletavad (et, sest, sellest et, samadel asjaoludel, mis tähendab, kuivõrd, sel põhjusel), täpsustavad (seejuures, näiteks, nagu, nii nagu, nimelt, kusjuures), järjestavad (kõigepealt, teiseks, esialgu, samas, järk-järgult, kuni, järgmine) ja rõhutavad (muidugi, jällegi, kahtlemata) seosesõnad. Tingimusi esitavaid ja kokkuvõtvaid seosesõnu esineb vähe. Seega liigub peatükisisene tekstistrateegia faktide lisamiselt nende täiendamisele, seletamisele ja vastandamisele.

Kõikide kohesioonivahendite järjekindel kasutamine ja õigete viitesuhete olemasolu parandab teksti arusaadavust. Kuigi analüüsi alusel võib väita, et enamik õpikuteksti on sidus, leidub siiski ka väärseoseid ja ebajärjekindlust.

\section{6. Õpikuteksti statistilisi omadusi}

\subsection{Terminid}

Üks teksti mõistetavust vähendav tegur on tundmatud sõnad, mille hulka kuuluvad terminid, võõrsõnad ja vähe kasutatavad sõnad. Nii keemia- kui ka geograafiaõpiku puhul annavad tooni terminid, seejuures on paljud 
neist ühtlasi võõrsõnad ja/või vähe kasutatavad sõnad. Peale võõrterminite esineb mõningal määral ka muid võõrsõnu (juveliir, atraktiivne, termiline, grandioosne), mille tähendust pole õpikutes otseselt selgitatud. Võõrsõnu on õpikutekstis vähe, põhiosa moodustavad terminid. Terminite kasutamise puhul on olulised järgmised aspektid: terminite seletamine, eristatavus, piisavalt sage esinemus. Samuti võiksid õpikutes olla sõnastikud, kuhu oleks koondatud omandatav terminoloogia (Puksand 2005). Mõlemas analüüsitud õpikus on sõnastik või aineregister olemas, see aga ei tähenda, et kõigile tekstis esinevatele terminitele oleks sealt võimalik seletust leida.

Geograafiaõpiku (Pihlak, Tõnisson 2005) esimese peatüki lõpuks peab õpilane tundma 30 termini tähendust. Omandatavad terminid on märgitud poolpaksu kirjaga ja eraldi esitatud iga peatüki kokkuvõttes. Liisa Tepp analüüsis oma magistritöös geograafiaõpikus antud omandamiseks mõeldud terminite esinemissagedust ja vaatles seda, kuidas termineid on seletatud õpiku sõnastikus ja peatükkides. Järgnevalt olgu esitatud mõned tüüpilised näited.

(11) Platvormi ehituses eristatakse kahte erinevat kihti: alus- ja pealiskorda. Aluskord lasub sügavamal ja koosneb kurrutatud moonde- ja tardkivimitest. Pealiskord lasub aluskorra peal ning koosneb settekivimitest. Aluskorda ja pealiskorda koos kutsutakse ka aluspõhjaks. (Pihlak, Tõnisson 2005: 10)

Selline seletus eeldab, et õpilane teab, mida tähendavad aluskord ja pealiskord, mis on kurrutatud moondekivimid, tardkivimid ja settekivimid. Niisiis, et mõista terminit aluspõhi, mille omandamist õpilaselt eeldatakse, peab õpilane tundma paljude teiste terminite tähendust. Kui tähendust ei teata, jääb termini platvorm meeldejätmine vaid mälule toetuvaks. Tähenduse seletuses kasutatud terminite järelevaatamiseks ja tähenduste kontrollimiseks pole õpiku sõnastikust abi, sest nende terminite tähendust seal pole.

(12) Moreenküngas - valdavalt moreense koostisega küngas, mis on tekkinud mandrijää tegevuse tagajärjel. (Pihlak, Tõnisson 2005: 194)

Definitsioon eeldab, et õpilane teab, mis on moreen ja mandrijää. Tundmatut seletatakse tundmatu kaudu: moreenküngas on moreense koostisega. Pealegi esineb termin moreenküngas õpikutekstis vaid kaks korda. Seda on liiga vähe, et termin kasutamisel kinnistuks. 
Seevastu esineb termineid, mida on hästi seletatud ja mis esinevad õpikutekstis piisavalt sageli selleks, et need õpilasele meelde jääksid. Näiteks on selline termin pinnakate.

(13) Pinnakate - Kvaternaari ajastu setete üldnimetus. Pinnakatte moodustavad mandrijäätumise käigus ja hiljem kujunenud setted (moreen, liiv, kruus, turvas jne). (Pihlak, Tõnisson 2005: 195)

Definitsioonis on selgitatud, millest pinnakate koosneb ning mis ajastust see pärineb. Seega eeldatakse, et õpilasele on geoloogilised ajastud tuttavad. Muidu on säärase asjaolu mainimine ülearune ning otseselt termini mõistmisele kaasa ei aita. Termin pinnakate esineb õpiku esimeses peatükis seitse korda. See tähendab, et ühe peatüki piires tegeletakse mõistega tihedalt ning see on eelduseks, et termin omandatakse.

Geograafiaõpiku terminikasutuse kohta võib öelda, et kohati esineb liiga keerulist defineerimist. Sageli sisaldab definitsioon mitmeid teisi termineid, mis teeb definitsiooni raskesti mõistetavaks. Omandamiseks mõeldud terminid ei kordu kuigi sageli ja seetõttu on neid raske meelde jätta. Üks kord esineb 10\% termineist, kaks korda 36,7\%, seega esineb üks või kaks korda 46,7\% termineist. See tähendab, et ligi pooled terminid esinevad õpikutekstis sedavõrd harva, et vaevalt need õppijale meelde jäävad. Lisaks jaotuvad terminid peatükkide vahel ebaühtlaselt. Õpikus on peatükke, kus ei tule omandada ühtki uut terminit, aga on ka neid, kus on vaja selgeks saada kuni seitse uut oskussõna. Osa oskussõnu puudub õpiku lõpus olevast sõnastikust ja selle asjaolu tõttu tuleb terminite tähendust ilmselt otsida teistest allikatest.

Keemiaõpik (Karelson, Tõldsepp 2011) on gümnaasiumiõpik ja tõenäoliselt eeldatakse, et suurem osa keemiaterminitest on põhikoolis juba omandatud. Analüüsis on loetud õppijale tuntuks näiteks järgmised oskussõnad (need ei esine õpiku aineregistris ega seletatud mõistete loendis): sünteesima, keemiline element, metalliline element, mittemetalliline element, perioodilisustabel, A-rühm, B-rühm, aatom, lihtaine, (metallide) aktiivsus, lisaks ka kõik keemiliste elementide ja ühendite nimetused (hüdroksiidid, oksiidid, sulfidid, süsinikdioksiid, ränidioksiid jne). Kui neid termineid ei peeta vajalikuks enam seletada, oleks siiski otstarbekas, et nende seletused oleksid õpiku lõpus mõistete loendis. Kui arvestusest välja jätta terminid, mis peaksid õpilasele varasemast tuntud olema, siis kolme analüüsitud peatüki uute terminite arv on 36. See teeb üle kümne 
uue termini peatüki kohta. Igal õpiku leheküljel on keskmiselt 3,5 uut terminit, mis omandada tuleks. Seejuures on üle poole neist sellised, mis esinevad vaid üks-kaks korda (kerged metallid, aheraine, räbu, aluminotermia, boksiit, särdamine). J. Mikk (1991, 1995) on soovitanud korraldada õppetöö nii, et ühes tunnis poleks vaja aktiivselt omandada enam kui üks uus mõiste. Analüüsitava teksti maht aga eeldab, et tunni jooksul omandataks üheksa-kümme mõistet. Kui lisada, et 51,3\% terminitest esineb vaid üks-kaks korda, siis on üsna mõistetav, miks keemia õppimine on õpilastele raske.

Analüüsitud geograafia- ja keemiaõpiku terminikasutusest ilmneb, et termineid on liiga palju, osa terminite esinemissagedus on sedavõrd harv, et vaevalt on neid võimalik omandada. Õpikute aineregistris ja terminisõnastikus esineb ebajärjekindlust - kõiki õpikutes kasutatud termineid sealt ei leia.

\subsection{Lause pikkus ja pikkade sõnede osakaal}

Loetavusindeks LIX on välja töötatud Rootsis ja seda on kasutatud teksti keerukuse hindamiseks. Statistiline meetod võtab arvesse lausete pikkust ja pikkade sõnede (7 ja rohkem tähte) esinemissagedust. Kuigi meetod on töötatud välja rootsi keele jaoks, on seda õnnestunult eesti keelele kohandanud Helin Puksand (2004). H. Puksand on võrrelnud LIXiga saadud tulemuste valiidsust õpetajate hinnangutega õpikutekstide kohta. Võrdlus näitas, et kõrge LIXi indeksiga õpikuid hindavad ka õpetajad keerulisemaks.

Keemiaõpiku loetavuse uuringus analüüsiti tekstikatket, mis sisaldas 1544 sõnet, tähe- ja numbrimärke oli 11 637. Sellise arvutuse tulemusena sai keskmiseks sõnepikkuseks 7,54 märki. Seitsme- ja enamatähelisi sõnesid oli 889 ehk 57,58\%. Analüüsis on lauseteks peetud ortograafilisi lauseid, st osalauseid ei peeta eraldi lauseteks. Lause pikkuse arvutamiseks analüüsiti 123 lauset ja selle alusel saadi lause keskmiseks sõnede arvuks 12,55. Seega ei saa väita, et laused oleksid liiga pikad. Pigem jäävad need lühemaks kui J. Miku soovitatud 15 sõnest koosnevad laused (Mikk 1991), mis on jõukohased 10. klassi õpilastele.

LIXi arvutamiseks liidetakse keskmine lausepikkus ja pikkade sõnede osakaal. Keemiaõpiku LIX on 70,13. Keskmise raskusastmega teksti LIX peaks jääma vahemikku 40-50. Raskeks tekstiks peetakse teksti 
LIXiga 50-60. Seega võib keemiaõpiku teksti pidada väga raskete kilda kuuluvaks.

Geograafiaõpikust uuriti 7508 sõnega tekstikatket. 613 lause analüüsi tulemusena on õpiku keskmine lausepikkus 12,25 sõnet. Pikkade sõnede (7 tähte ja enam) protsent oli 50,70. See tähendab, et hoolimata sellest, kui pikad on laused, on keskmiselt pooled sõned pikemad kui seitse tähte. Geograafiaõpiku LIX on 62,95. Seega võib pidada õpikuteksti taas väga raskeks.

Statistiliste näitajate alusel on mõlema õpiku lausepikkus ligilähedane: 12,55 ja 12,25. Lausepikkuse poolest jäävad õpikutekstid soovitatava piiresse (Mikk 1991), küll aga on suur pikkade sõnede osakaal, mis teeb teksti keerukaks ja raskesti mõistetavaks.

$\mathrm{K}$. Kerge on uurinud lause pikkust erinevates keelevaldkondades. Tulemused olid järgmised: igapäevasuhtluses esines 9,15 sõna lauses; ilukirjanduses 10,01; ajakirjanduses 13,79; teaduses 12,61; õiguses 24,79. Kui jätta kõrvale õiguskeel, siis on keskmine lausepikkus 11,39 sõna. (Kerge 2002: 42) Võttes arvesse seda, et tekstid, millega õpilane koolis kokku puutub, peavad õpilast ette valmistama tekstideks väljaspool kooli, siis on 12-sõnaline keskmine lausepikkus üsnagi optimaalne.

\section{Kokkuvõte ja järeldused}

Õpikute keelekasutuse keerukus on seotud mitme parameetriga. Kõigepealt sellega, kuidas ainevaldkonna infot esitatakse, milline pilt ainest keelevalikute tulemusena luuakse. Tähistusfunktsiooni analüüs näitas, et inimtegelased on õpikutekstist taandatud, teksti keskseteks osalisteks on ained ja abstraktsed mõisted. Tekstis kujutatavad protsessid on enamasti eksistentsiaalsed, passiivsed ja staatilised, mis on iseloomulik eritlevale tekstitüübile ja lähendab õpikuteksti teadustekstile. Teadustekstist eristab õpikut aga väidete esitamine kindlate tõdedena, mille paikapidavuses pole põhjust kahelda. Väljenduslaad on neutraalne, omadussõnad on enamasti objektiivsed, hinnangusõnu on väga vähe. Analüüsitud materjalis on silmatorkavalt suur osa nimetamisega seotud väljenditel, mis teevad teksti kohati ühetooniliseks. Nimetamine on omakorda seotud oskussõnade suure sagedusega. Terminid esinevad õpikutekstis ebaühtlaselt, on tekstiosi, kus terminite hulk on väga suur, samas võib mõni tekstiosa piirduda vaid mõne üksiku termini esitamisega. 
Interpersonaalse funktsiooni analüüs näitas, et lugejale on peatükkide sissejuhatavas osas kujundatud aktiivse uurija roll, põhitekstis aga passiivse vastuvõtja roll. Selline vastuvõtja ei kahtle ega esita küsimusi. Autorid kirjutavad teadja positsioonilt, arutelust on hoidutud.

Tekstuaalse funktsiooni analüüsi puhul vaadeldi lähemalt infostruktuuri ja sidususvahendeid. Analüüsist võib järeldada, et enamasti on õpikutekst sidus, vaid üksikutel juhtudel oleksid vajalikud täpsemad viitesuhted. Infostruktuuri analüüs näitas, et vana ja uue info esitamises esines kõrvalekaldeid. Infoedastuse korrastamine aitaks kindlasti õpikuteksti loetavust parandada.

Kvantitatiivse tekstianalüüsi meetodit kasutades selgus, et uute mõistete hulk õpikutekstides on soovitatust märgatavalt suurem. Ka ei esine uued mõisted sedavõrd sagedasti, et neid oleks võimalik omandada. Üks või kaks korda esinevad mõisted ei moodusta ülejäänud õppetükiga piisavalt tihedat seosevõrku ja õpilane ei pruugi nende tähendust mõista. Kui valida õppetükki uusi mõisteid vähem, siis saaks neid põhjalikumalt selgitada ja samas väheneks selliste harva esinevate terminite hulk, mis pidurdavad lugemist ja mille meeldejätmine on raske.

Keskmise lausepikkuse ja pikkade sõnade osakaalu mõõtmine LIXi indeksiga näitas, et loodusteaduste õpikute laused on optimaalse pikkusega. Pikkade sõnade osakaal on aga liiga suur. Vaadeldud õpikute LIXi indeks on 70 või läheneb sellele, mis tähendab, et vaadeldud õpikuid võib keele keerukuse poolest lugeda väga raskeks.

Eelnevast analüüsist võib järeldada, et loodusteaduste õpikute keel on pigem keeruline kui lihtne. Seda põhjustavad eelkõige terminite rohkus, nende vähene korduvus ning erialase sõnavara kasutamise suur osakaal. Vildakad viitesuhted ja segane infostruktuur ei soosi teksti lugejasõbralikkust. Üks võimalus, kuidas õpikuteksti lugejale vastuvõetavamaks muuta, on autorite harimine teksti keerukusparameetrite vallas. Samuti aitaks kindlasti asjalik toimetajatöö, mis heade keelekasutustavade kõrval hindaks õigesti teksti vastuvõtja ealistest iseärasustest tulenevat vastuvõtuvõimet. 


\section{Materjali allikad}

Karelson, Mati, Aarne Tõldsepp 2011. Keemia. Üldine ja anorgaaniline keemia gümnaasiumile. Tallinn: Koolibri.

Pihlak, Liisa-Kai, Andres Tõnisson 2005. Geograafia põhikoolile: Eesti ja Euroopa. Tallinn: Koolibri.

\section{Kirjandus}

Asser jt 2004 = Hiie Asser, Heiki-Jaan Kaalep, Siret Linnas, Jaan Mikk, Muischnek, Merje Songe, Heli Uibo. Õpikute keerukuse analüüs arvutitel. Toimiv keel II: töid rakenduslingvistika alalt. Koost. Helle Metslang. Toim. Maria-Maren Sepper, Jane Lepasaar. (= Tallinna Pedagoogikaülikooli eesti filoloogia osakonna toimetised 3.) Tallinn: Tallinna Pedagoogikaülikooli kirjastus, 72-84.

Baram-Tsabari, Ayelet, Anat Yarden 2005. Text genre as a factor in the formation of scientific literacy. - Journal of Research in Science Teaching 42 (4), 403-428. http://dx.doi.org/10.1002/tea.20063.

EKAK = Eesti keele arengukava 2011-2017; http://www.hm.ee/index.php?03238 (03.12.12).

EKG 1993 = Mati Erelt, Reet Kasik, Helle Metslang, Henno Rajandi, Kristiina Ross, Henn Saari, Kaja Tael, Silvi Vare. Eesti keele grammatika II. Süntaks. Lisa: Kiri. Peatoim. Mati Erelt, toim. Tiiu Erelt, Henn Saari, Ülle Viks. Tallinn: Eesti Teaduste Akadeemia Keele ja Kirjanduse Instituut.

Halliday, Michael Alexander Kirkwood 2007 (1993). Writing science: literacy and discursive power. - The Language of Science. Ed. Jonathan J. Webster. (= Collected Works of M. A. Halliday. Volume 5.) London, New York: Continuum, 199-225.

Halliday, Michael Alexander Kirkwood 2004. An Introduction to Functional Grammar. Third edition. Revised by Christian M. I. M. Matthiessen. London: Hodder Arnold.

Halliday, Michael Alexander Kirkwood, Ruqaiya Hasan 1976. Cohesion in English. London: Longman.

Holbrook, Jack, Miia Rannikmäe 2007. Nature of science education for enhancing scientific literacy. - International Journal of Science Education 29 (11), 1347-1362. http://dx.doi.org/10.1080/09500690601007549.

Kasik, Reet 2007. Sissejuhatus tekstiõpetusse. Tartu: Tartu Ülikooli kirjastus.

Kerge, Krista 2002. Varieties of language and mother tongue teaching orientation. - Learning and educational media. Ed. Jaan Mikk, Veijo Meisalo, Hasso Kukemelk, Mike Horsley. [= The third IARTEM volume.] Tartu: The International Association for Research on Textbooks and Educational Media, University of Tartu, 230-236. 
Kerge, Krista 2003. Keele variatiivsus ja mine-tuletus allkeelte süntaktilise keerukuse tegurina. (= Tallinna Pedagoogikaülikooli humanitaarteaduste dissertatsioonid 10.) Tallinn: Tallinna Pedagoogikaülikooli kirjastus.

Kukemelk, Hasso 1990a. Reaalainete õppeteksti omandamisaja sõltuvus tema karakteristikutest. Doktoriväitekiri. Käsikiri Tartu Ülikooli raamatukogus.

Kukemelk, Hasso 1990b. Õpiaja sõltuvus õppetekstist. - Haridus 5, 8-11.

Mikk, Jaan 1980. Teksti mõistmine. Tallinn: Valgus.

Mikk, Jaan 1991. Didaktika küsimusi: loengukonspekt üliõpilastele. Tartu: Tartu Ülikool.

Mikk, Jaan 1995. Mida hinnata õppekirjanduses. - Haridus 2, 27-32.

Mikk, Jaan 2000. Textbook: Research and Writing. Frankfurt am Main: Lang.

Mikk, Jaan 2003. Kuidas hinnata õppeteksti keerukust? - Õpetajate Leht 01.08, $6-7$.

Puksand, Helin 2004. Loetavusindeksi LIX sobivusest eestikeelsele tekstile. - Tekstid ja taustad III. Lingvistiline tekstianalüüs. Toim. Reet Kasik. (= Tartu Ülikooli eesti keele õppetooli toimetised 28.) Tartu: Tartu Ülikooli kirjastus, 108-119.

Puksand, Helin 2005. Terminoloogia õpikutes. - Tekstid ja taustad IV. Tekstiliigivaatlusi. Toim. Reet Kasik. (= Tartu Ülikooli eesti keele õppetooli toimetised 29.) Tartu: Tartu Ülikooli kirjastus, 68-81.

Puksand, Helin, Krista Kerge 2011. Õpiteksti analüüs kirjaoskuse omandamise kontekstis. - Emakeele Seltsi aastaraamat 57 (2011). Peatoim. Mati Erelt. Tallinn: Teaduste Akadeemia Kirjastus, 167-217.

Õppekava 2011 = Vabariigi Valitsuse 06.01.2011 . a määruse nr 2 „Gümnaasiumi riikliku õppekava” lisa 4 p 1 „Ainevaldkond „Loodusained””; https:// www.riigiteataja.ee/aktilisa/1140/1201/1002/VV2_lisa4.pdf(2.10.2012).

Yarden, Anat 2009. Reading scientific texts: adapting primary literature for promoting scientific literacy. - Research in Science Education 39, 307-311. http://dx.doi.org/10.1007/s11165-009-9124-2. 


\title{
About the language of natural science textbooks
}

\author{
Kersti Lepajõe, Kärt Talsi, \\ Liisa Tepp
}

The paper provides an analysis of the language of natural science textbooks based on the chemistry textbook by M. Karelson and A. Tõldsepp and the geography textbook by L.-K. Pihlak and A. Tõnisson. The texts were analysed by methods of text linguistics. The analysis shows that the main actors in the text are substances and abstract concepts. Humans and their activities have a minimal role in the text. The processes described in the textbook are mostly existential, passive, and static, which can be explained by the specific qualities of school texts as a genre. The activity level of the reader is low, except for the introductions and exercises. In the main narrative component, the reader performs the role of a passive recipient who has no doubts, does not ask any questions, or argue with the text. The writing in the textbooks is mostly cohesive; there are a few cases where the information is not presented in the logical order. Although sentences in the textbooks are of average length, they reveal a high rate of long words and difficult terms. In natural science textbooks, the prevalence of terms is so high that it interferes with readability. In addition, almost half of the terms are used only once or twice, which makes it more difficult to acquire the meaning of the terms. The language of natural science textbooks is complex. Such language use does not promote mastering the subject.

Keywords: textbook readability, ideational function, interpersonal function, textual function, terms, long words, sentence length, difficulty of text, Estonian language

Kersti Lepajõe

eesti ja üldkeeleteaduse instituut

Tartu Ülikool

Jakobi 2-429

51014 Tartu

Kersti.Lepajoe@ut.ee 


\section{Kärt Talsi}

Kirjastus Avita

Vallikraavi 7/9

51003 Tartu

karttalsi@gmail.com

Liisa Tepp

Hugo Treffneri gümnaasium

Munga 12

51007 Tartu

liisa.tepp@htg.tartu.ee 